\title{
Assessment of the oxidative metabolism of calves' bronchoalveolar cells: comparison between NBT and fluorimetric techniques
}

\author{
Mensuração do metabolismo oxidativo de células broncoalveolares \\ de bezerros: comparação entre as técnicas de NBT e fluorimétrica \\ Bruna Artner $^{1}$ (D), Angela Reck ${ }^{1}$ (D), Alessandra Mayer Coelho' ${ }^{1}$, \\ Julio José Prediger ${ }^{1}$ (D), Desiree Vera Pontarolo' ${ }^{1}$, Heloisa Godoi Bertagnon ${ }^{1 *}$ (D)
}

\begin{abstract}
Evaluation of alveolar macrophage functions of cattle is an important tool in order to assess whether measures taken during the cattle husbandry can decrease the respiratory tract defense. The aim of this study was to determine whether dexamethasone used at therapeutic dose can affect the oxidative metabolism of alveolar macrophages of cattle. This was evaluated by two tests, the fluorometric and colorimetric. The similarity of the results was studied, using alveolar macrophages of six healthy cattle, obtained from bronchoalveolar lavage on a basal and an immunosuppressant moment after the application of dexamethasone. For the fluorometric test, alveolar macrophages were incubated with Staphylococcus aureus and 2'-7'dichlorohidroflurescein, and analyzed by flow cytometer. For the colorimetric test, alveolar macrophages were incubated with Phorbol 12- miristate-13 acetate and nitroblue tetrazolium, dissolved and analyzed in a spectrophotometer. It was noted that dexamethasone therapeutic dose $(0.05 \mathrm{mg} / \mathrm{kg})$ reduced the functions of alveolar macrophages from healthy bovine. This result was observed by both tests with the difference that the flow cytometry assay was more informative for identifying which specific cellular function has been compromised.
\end{abstract}

KEYWORDS: reactive oxygen species; immunity; alveolar macrophage.
RESUMO: A avaliação das funções de macrófagos alveolares de bovinos é uma ferramenta importante no intuito de analisar se medidas adotadas durante a criaçáo desses animais diminuem a defesa do trato respiratório, aumentando a susceptibilidade à pneumonia. O objetivo deste trabalho foi verificar se a dexametasona em dose terapêutica afeta o metabolismo oxidativo de macrófagos alveolares de bovinos por meio de duas provas, a fluorimétrica e a colorimétrica, avaliando a similaridade dos resultados. Para tanto, utilizaram-se macrófagos alveolares de seis bovinos sadios, obtidos por meio de lavados broncoalveolares em um momento basal e em um momento imunossupressor, após a aplicação da dexametasona. Na prova fluorimétrica, os macrófagos alveolares foram incubados com Staphylococcus aureus e o fluorófilo 2'-7' diclorohidrofluresceína e analisados por citometria de fluxo. $\mathrm{Na}$ prova colorimétrica, os macrófagos alveolares foram incubados com Phorbol 12- miristate-13 acetate e nitroazul de tetrazolium, dissolvidos e analisados em espectofotômetro. Observou-se que a dexametasona em dose terapêutica $(0,05 \mathrm{mg} / \mathrm{kg})$ reduziu as funçóes dos macrófagos alveolares de bovinos sadios, sendo este resultado obtido em ambas as provas, com a diferença de que o teste de citometria de fluxo foi mais esclarecedor por identificar qual função celular específica foi comprometida.

PALAVRAS-CHAVE: espécies reativas de oxigênio; imunidade; macrófago alveolar. 


\section{INTRODUCTION}

Bronchopneumonia is a relevant condition in bovines that represent economic losses in livestock and foster development of studies to minimize its occurrence (ACKERMAN et al., 2010). The most usual form, the bovine respiratory complex, is directly related to management factors that compromise immunity of the respiratory tract, due to reduction in effectiveness of the innate immune cells leading to colonization and multiplication of commensal bacteria within the bronchoalveolar region (BERTAGNON et al., 2011; BELLINAZI et al., 2013; COBB et al., 2014).

It is known that the first line of defense against these microorganisms is carried out by alveolar macrophages (ACKERMAN et al., 2010). Therefore, the knowledge about the alveolar macrophage activity is important to identify factors that may compromise its function, as it can increase the risk of bronchopneumonia.

Among the alveolar macrophages' functions, the most important is the phagocytosis of antigenic particles and their intracellular elimination by enzymes and cytoplasmic granules - the oxidative metabolism being highlighted as the most important (BURGOS et al., 2011). In this process, phagocytosis by itself activates the intracellular nicotinamide adenine enzyme dinucleotide phosphate (NADPH) that, when transferring electrons to cytosol, forms oxygen reactive species (ROS) such as anion superoxide and hydrogen peroxide, from which other oxidizing metabolites derive targeted to eliminate internalized pathogens (BURGOS et al., 2011).

Despite this information, it should be highlighted that during the buiatric practice, dexamethasone, an anti-inflammatory drug, is used for management of several bovine diseases, such as ketonemia, traumatic processes, grave infections and pregnancy disorders (e.g. udder edema, paresis of peripheral nerves and induced deliveries) (RADOSTITS et al., 2002). This drug inhibits the functions of blood leucocytes and tissue macrophages by modulating the release of cytokines, inflammatory mediators and ROS generation (TORRES et al., 2012), avoiding that the animal's own immunologic response to the disease cause intense tissue damage and further aggravation of the condition (MALAZDREWICH et al., 2004). The use of this drug may generate immunosuppression in phagocytes, including macrophages (TORRES et al., 2012), which would increase the risk of infectious diseases as bronchopneumonia in bovines (RADOSTITS et al., 2002).

However, its effect is dose-dependent, and a major part of dexamethasone effects were noted in tissue macrophages and not in the alveolar ones. Furthermore, these are "in vitro" studies with supra pharmacological doses (WEISS et al., 2015), which may not reflect the reality of its therapeutic application. Therefore, the doubt persists whether this drug, when used in therapeutic doses, may or may not reduce the respiratory tract defense (JERICÓ; MARCO, 2011).

It should also be highlighted that the most used techniques for intracellular ROS evaluation are the fluorimetric and chemoluminescense ones, which require expensive equipment and reagents as well as personal capacitation (DAHLGREN; KARLSSON, 1999). The colorimetric tests are simpler and cheaper, however less sensitive (DAHLGREN; KARLSSON, 1999). Additionally, these techniques are usually targeted to neutrophils (FREITAS et al., 2009), with only a few researches involving bovine's alveolar macrophages (BATISTA et al., 2012).

Aiming at increasing the sensitivity of a colorimetric test, CHOI et al. (2006) proposed that the NBT reduction technique would change the evaluation achieved in percentage of neutrophils positive to NBT identified by optic microscopy by a colorimetric method. It checks the intensity of NBT reduced by neutrophils by spectrophotometry, thus generating a more accurate quantitative result. In addition, they achieved success in using such a technique to assess the alveolar macrophage's oxidative metabolism for humans and mice.

Against the foregoing, this work aimed at checking whether dexamethasone in therapeutic doses affects the healthy bovine's alveolar macrophages oxidative metabolism by means of two tests, the fluorimetric and the colorimetric, and by assessing the similarity of results.

\section{MATERIAL AND METHODS}

This research was approved by the ethics committee for animal use/UNICENTRO (009/2015).

Six female and healthy bovines aged 20 months ( \pm 2 months) and weighing $298 \mathrm{~kg}$ ( $\pm 50 \mathrm{~kg}$ ) from the Jersey breed, coming from the UNICENTRO Unidade Didática de Bovinos Leiteiros (Dairy Cattle Didactic Unit) were used. The assessment of the innate immune function was carried out in two moments: the basal one (M1) and the immunosuppressing one (M2), 60 minutes after the administration of dexamethasone IM at the $0.05 \mathrm{mg} / \mathrm{kg}$ dose. A 16-day interval occurred between collection of the basal and immunosuppressing moments.

For the assays, samples of bronchoalveolar lavages were collected by nasotracheal bronchoscopy. The animals were contained in trunk and sedated with xilazine (Anasedan ${ }^{\circledR}$ - cevaBRA) at the dose of $0.01 \mathrm{mg} / \mathrm{kg}, \mathrm{IV}$, as per the technique described by BATISTA et al. (2012). Following sedation, a fiberscope (equiboardvet $9830^{\circledR}$ ) was inserted through the nostril towards the bronchi up to find resistance to the passage of the probe; following this, $30 \mathrm{~mL}$ of $0.9 \%$ saline at room temperature was injected and immediate aspiration was made with a vacuum pump (A-45 plus aspirator olidef $c z^{\circledR}$ ), with the vacuum gauge graded up to 29 pol. $\mathrm{Hg}$ equivalent to $760 \mathrm{~mm} \mathrm{Hg}$. The procedure was repeated later on the left bronchus.

The fluorimetric assessment was carried out by flow cytometry, according to the technique recommended by KAMPEN et al. (2004), with modifications. It was assessed the percentage of cells that phagocytized Staphylococcus aureus and produced intracellular ROS by oxidation of 2.7-dichloro-dihyidro-fluorescein diacetate (DCFH - Life technology $\left.{ }^{\circledR}\right)$ into dichlorodihydro-fluorescein diacetate fluorescent molecule (DCFH). 
The respiratory cells were washed with PBS, underwent the feasibility test by trypan blue and were adjusted at the $2 \times 10^{6}$ live cells $/ \mathrm{mL}$. Later on, $100 \mu \mathrm{L}$ out of this cellular suspension were incubated with $200 \mu \mathrm{L}$ DCFH $(0.3 \mathrm{mM}$ at $1.2 \%$ PBS solution) with and without stimulus ( $2 \mu \mathrm{L}$ of Staphylococcus aureus conjugated with AlexaFlour 594 - Life technology ${ }^{\circledR}$ ) during 30 minutes at $37^{\circ} \mathrm{C}$. After the reaction was stopped with the addition of $2,000 \mu \mathrm{L}$ of cold EDTA $(3 \mathrm{mM})$, the cells were suspended with $400 \mu \mathrm{L}$ of PBS and analyzed with a flow cytometer (Accury c $6^{\circledR}, \mathrm{BD}$ ). A total of 10,000 events was collected from each tube and analyzed in the Flowjo ${ }^{\oplus}$ (Tree Star Inc. Ashland, OR; version 10.0 for Windows) software.

Due to the non-separation of cellular populations in accordance with the granularity cytology (SSC - sidescatter cells) and size (FSC - forwardscatter cells), the self-fluorescence of the alveolar macrophages was used, as described by SOETHOUT et al. (2004). There was an analysis of the the average fluorescence intensity (FI) and the percentage of their respective phagocytosis activities and production of ROS, basal and stimulated.

The NBT test colorimetric evaluation was carried out according to the technique recommended by $\mathrm{CHOI}$ et al. (2006). It were incubated $100 \mu \mathrm{L}$ of the bronchoalveolar cellular suspension with equal parts with $1 \%$ NBT solution $\left(\right.$ Sigma $\left.^{\circledR}\right)$ stimulated with $5 \mu \mathrm{L}$ of Phorbol 12- miristate-13 (PMA at $300 \mathrm{mg} / \mathrm{mL}$, Sigma ${ }^{\circledR}$ ) during $30 \mathrm{~min}$ at $37^{\circ} \mathrm{C}$. After the reaction was stopped with the addition of 2,000 $\mu \mathrm{L}$ of cold EDTA $(3 \mathrm{mM})$, the external NBT was removed after lavage with methanol $\left(S_{y n t h}{ }^{\circledR}\right)$, and the cells were dissolved with $\mathrm{KOH}\left(\mathrm{Synth}^{\circledast}\right)(3 \mathrm{M}, 120 \mu \mathrm{L})$ and DMSO (Dimesol ${ }^{\oplus}$ - Marcolab) $(99 \%, 140 \mu \mathrm{L})$. The samples were read by spectrophotometry at $630 \mathrm{~nm}$.

The statistical analysis of data was conducted using the InstatGraphpad ${ }^{\circledR}$ software. To assess the differences between the averages of the results achieved, $t$-tests for paired samples were conducted. For the correlation test, the Pearson coefficient was used. For all the results, the analyses presenting $\mathrm{p} E$ 0.05 were regarded as significant.

\section{RESULTS AND DISCUSSION}

It may be noted that dexamethasone reduced the alveolar macrophages' (AM) oxidative metabolism, confirmed by the AM percentage producing ROS with stimulation $(\mathrm{DCFH})$ $(\mathrm{p}=0.03)($ Fig. 1$)$ and by the NBT test absorbance $(\mathrm{p}=0.02)$. However, it did not interfere with the other variables (Table 1).

Although no statistical difference has been noted between the AM percentage producing ROS basal before and after the application of dexamethasone, this function behavior was very similar to the one of AM producing ROS under stimulation.

These differences were also found by BOHLAND et al. (2008), who justified that in the stimulated oxidative metabolism, the use of bacteria simulated an in vitro infection, and that phagocytosis is required to trigger the oxidative metabolism, thus leading to a more reliable result for a natural infection. In the basal test, the oxidative metabolism is spontaneous and leads to more variability of results, as well as a higher average standard error, which culminated in the lack of statistical difference for this variable. Possibly, a higher sampling number could identify a significant statistic value.

Maintenance of phagocytosis followed by reduction in stimulated ROS indicates that dexamethasone reduced effectiveness of elimination of internalized particles, thus characterizing compromise of the alveolar macrophages' defense activities in bovines (CÔRTES et al., 2013).

As regards the fluorescence intensity ( $\mathrm{FI}$ ), it was noted that dexamethasone promoted a significant increase of ROS stimulated by AM $(\mathrm{p}=0.05)$ and did not interfere with the other variables (Table 2).

FI indicates the number of fluorescent particles within each cell (BOHLAND et al., 2008); therefore, it may be noted that in $\mathrm{M} 2$, the AM produced ROS under stimulation at higher amounts, as compared to M1. However, the reduction in the percentage of AM producing stimulated ROS in this same moment was confirmed. This sole fact does not allow identifying whether the function reduction (\%) has been compensated
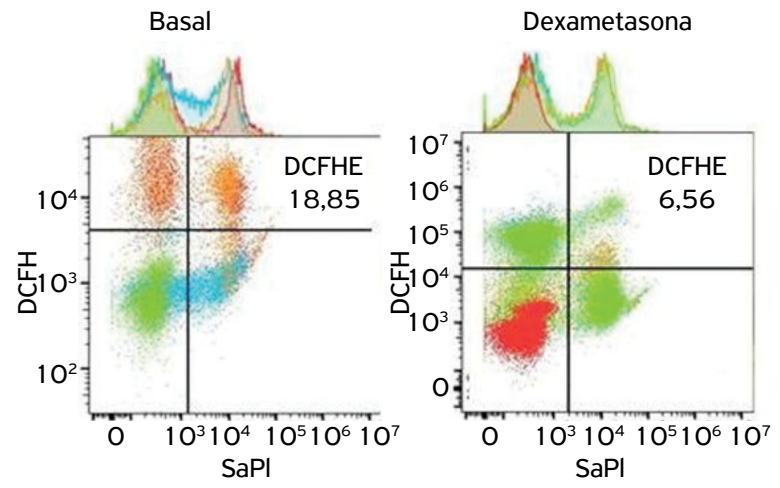

Each colour represents one animal. DCFH: AM percentage producing ROS basal; SaPI: AM percentage that phagocytized S aureus; DCFHE: AM percentage producing ROS with stimulation by $S$ aureus.

Figure 1. Cytogram of alveolar macrophage's ROS stimulated calves at basal and immunosuppressing moment.

Table 1. Means (SEM) AM percentage and their functions of calves at basal (M1) and immunosuppressing moment (M2)

\begin{tabular}{|ccccc|}
$\begin{array}{l}\text { Moments/Alveolar } \\
\text { Functions AM (\%) }\end{array}$ & $\begin{array}{c}\text { DCFH } \\
\text { (\%) }\end{array}$ & $\begin{array}{c}\text { SaPI } \\
(\%)\end{array}$ & $\begin{array}{c}\text { DCFHs } \\
(\%)\end{array}$ & $\begin{array}{c}\text { NBT } \\
\text { (OD) }\end{array}$ \\
\hline M1 & 38.69 & 33.62 & 18.85 & 0.18 \\
\hline 75.63 & 9.35 & 7.13 & 4.43 & 0.029 \\
\hline 4.06 & & & & \\
\hline M2 & 23.55 & 40.75 & 6.65 & 0.09 \\
\hline 68.58 & 2.36 & 5.96 & 1.46 & 0.016 \\
\hline 1.59 & & & & \\
\hline P & 0.21 & 0.41 & 0.03 & 0.02 \\
\hline
\end{tabular}

AM: alveolar macrophage; DCFH: AM percentage producing ROS basal; SaPI: AM percentage that phagocytized S aureus; DCFHs: AM percentage producing ROS with stimulation by $S$ aureus; NBT: optical density of reduced NBT. 
by the increase of the other (FI). However, as the phagocytosis percentage and FI were held constant at both moments, there were cells that phagocytized bacterial particles and produced higher amounts of ROS, as well as those that did not produce ROS in M2, leading to the non-elimination of intracellular bacteria. This is an indication that dexamethasone has caused reduction in the AM function, as it had been suggested by FEKETY (1992), DOHERTY et al. (1995) and TORRES et al. (2012) when conducting studies in other animal species.

As for the fluorimetric test by flow cytometry and the colorimetric by NBT reduction, it was found only a strong and significant correlation between the AM percentage that produced ROS under stimulation and the NBT reduction $(\mathrm{R}=0.94$ and $\mathrm{p}<0.0001)$ (Table 3$)$.

Different stimuli activate ROS production by several mechanisms (DUCUSIN et al., 2001); while the Staphylococcus aureus triggers ROS production by phagocytosis, PMA triggers

Table 2. Means (SEM) of AM fluorescence intensity (FI) of calves at basal (M1) and immunosuppressing moment (M2).

\begin{tabular}{|cccc|} 
& DCFH (FI) & SaPI (FI) & DCFHs (FI) \\
\hline \multirow{2}{*}{ M1 } & $349,948.93$ & $6,369.50$ & $403,424.00$ \\
\cline { 2 - 4 } & $200,171.00$ & $1,739.30$ & $209,202.00$ \\
\hline \multirow{2}{*}{ M2 } & $640,499.67$ & $3,782.50$ & $2,077.000 .00$ \\
\cline { 2 - 4 } & $299,200.00$ & 810.28 & $529,031.00$ \\
\hline P & 0.52 & 0.26 & 0.05 \\
\hline
\end{tabular}

AM: alveolar macrophage; DCFH: AM fluorescence intensity producing ROS basal; SaPI: AM fluorescence intensity that phagocytized S aureus; DCFHs: AM fluorescence intensity producing ROS with stimulation by $S$ aureus.

Table 3. Pearson correlation (R) of $A M$ functions of calves at basal (M1) and immunosuppressing moment (M2).

\begin{tabular}{lcccc} 
Pearson & \multicolumn{2}{c}{$\%$} & \multicolumn{2}{c}{ FI } \\
\cline { 2 - 5 } correlation & $\mathbf{R}$ & $\mathbf{P}$ & $\mathbf{R}$ & $\mathbf{P}$ \\
\hline DCFH x NBT & 0.17 & 0.59 & 0.22 & 0.47 \\
\hline DCFHs x NBT & 0.94 & $<0.0001$ & -0.16 & 0.6 \\
\hline SaPI x NBT & 0.23 & 0.46 & -0.05 & 0.85 \\
\hline
\end{tabular}

AM: alveolar macrophage; DCFH: AM producing ROS basal; SaPI: AM that phagocytized S aureus; DCFHs: AM producing ROS with stimulation by $S$ aureus; NBT optical density of reduced NBT. the process by activation of C-protein. However, KAMPEN et al. (2004) reached similar results in ROS production of bovines' polymorphonuclear by using both stimuli in the same doses of the present research, indicating that this factor probably does not hinder the comparison between both tests.

The fluorimetric test (flow cytometry) allows analyzing separate cellular functions: phagocytosis and production of basal and stimulated ROS. These data indicate a general behavior when the results were expressed in percentage, and the efficiency of each functions when results were expressed in FI (KAMPEN et al., 2004).

This approach details the exact cellular functions are compromised in alveolar macrophages by dexamethasone, showing that the drug decreased the cellular activity by reduction of AM percentage producing ROS under stimulation.

On the other hand, the colorimetric test of NBT reduction identifies both the phagocytosis and ROS production simultaneously (PARK; GOOD, 1970; BERTAGNON et al., 2014), and does not make distinction between $A M$ and other cells existing in the respiratory tract that perform these functions, as well as in the percentage or efficiency of these cells (CHOI et al., 2006). Although being a more general evaluation, this test was also effective in identifying that the drug caused damage to the respiratory cells' function. As AM is the predominant cell type of healthy calves' bronchoalveolar tract (BERTAGNON et al., 2011; BATISTA et al., 2012), it may be extrapolated that NBT has identified reduction in their activity.

\section{CONCLUSION}

It is concluded that both tests were effective in identifying that dexamethasone, in the $0.05 \mathrm{mg} / \mathrm{kg}$ therapeutic dose, may reduce the oxidative metabolism of healthy calves' alveolar macrophages. The fluorimetric test by flow cytometry was more sensitive as it could identify which specific cellular function has been compromised.

\section{ACKNOWLEDGMENTS}

Financing process PIBIC/Fundação Araucária.

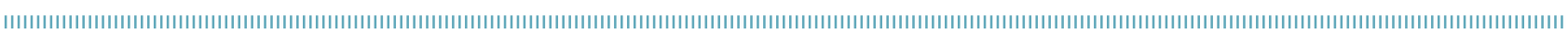
REFERENCES

ACKERMAN, M.R.; DERSCHEID, R.; ROTH, J.A. Innate immunology of Bovine Respiratory Diseases. Veterinary Clinics of North America: Food Animal Practice, n.26, p.215-228, 2010.

BATISTA, C.F.; BLAGITZ, M.G.; SANTOS, B.P.; BERTAGNON, H.G.; PARRA, A.C.; VIANNA, R.S.; DE LUCCA, G.G.; LIMA, D.M.; SANTOS, D.S.; DELLALIBERA, A.M. Maturation of mononuclear phagocytes in the lungs of young calves-In vitro study. Journal of Dairy Science, n. 10, p.5909-5915, 2012.
BELLINAZZI, J.B.; BERTAGNON, H.G.; BATISTA, C.F.; DOS SANTOS, B.P.; BARBOSA LIMA, M.G.; LIMA, D.M.; BENESI, F.J.; DELLA LIBERA, A.M.P.M. Efeitos do estresse da orquiectomia na citologia broncoalveolar de bezerros da raça Holandesa. Pesquisa Veterinária Brasileira, n.33, p.93-98, 2013.

BERTAGNON, H.G.; ESPER, G.V.Z.; EMANUELLI, M.P.; PELLEGRINE, L.G. Influência meteorológica no leucograma e na população citológica do trato respiratório de bezerros. Pesquisa Veterinária Brasileira, n.31, p.244-246, 2011. 
BERTAGNON, H.G.; SILVA, E.B.; CONNEGLIAN, M.M.; NEUMANN, M.; ESPER, G.V.Z.; BASTOS, G.P.; PEREIRA, J.R. Ação imunomoduladora da vitamina $E$ na imunidade sistêmica e da glândula mamária de bovinos leiteiros alimentados com silagem. Semina: Ciências Agrárias, Londrina, n.35, p.857-866, 2014.

BOHLAND E.S.A.; ROCHA, V.M.; CYRILLO, F.C.; BENESI, F.J. Efeito do tempo de conservação de polimorfonucleares do sangue de bezerros sobre o metabolismo oxidativo e a atividade de fagocitose de Escherichia coli. Brazilian Journal of Veterinary Research and Animal Science, n.45, p.48-56, 2008.

BURGOS, R.A.; CONEJEROS, I.; HIDALGO, M.A.; WERLING, D.; HERMOSILL, A. Calcium influx, a new potential therapeutic target in the control of neutrophil-dependent inflammatory diseases in bovines. Veterinary Immunology and Immunopathology, n. 143 , p. 1-10, 2011.

CHOI, S.; KIM, J.W.; CHA, Y.N.; KIM, C.A Quantitative Nitroblue Tetrazolium Assay for Determining Intracellular Superoxide Anion Production in Phagocytic Cells. Journal of Immunoassay and Immunochemistry, n.27, p.31-44, 2006.

COBB, C.J.; OBEIDAT, B.S.; SELLERS, M.D.; PEPPER-YOWELL, A.R.; BALLOU, M.A. Group housing of Holstein calves in a poor indoor environment increases respiratory disease but does not influence performance or leukocyte responses. Journal of Dairy Science, n.97, p.3099-3109, 2014.

CÔRTES, M.A.; FRANÇA, E.L.; REINAQUE, A.P.B.; SCHERER, E.D.; HONORIO-FRANÇA, A.C. Imunomodulação de fagócitos do sangue humano pelo extrato de Strychnos pseudoquinas $p$ adsorvido em microesferas de polietilenoglicol. Polímeros, n.23, p.402-409, 2013.

DAHLGREN, C.; KARLSSON, A. Respiratory burst in human neutrophils. Journal Immunology Methods, n.232, p.3-14, 1999.

DOHERTY, M.L.; BASSETT, H.F.; QUINN, P.J.; DAVIS, W.C. Effects of dexamethasone on cell-mediated immune responses in cattle. American Journal of Veterinary Research, n.56, p. $1300-$ 1306, 1995.

DUCUSIN, R.J.; SARASHINA, T.; UZUKA, Y.; TANABE, S.; OHTANI, $M$. Phagocytic response of bovine polymorphonuclear leukocytes to different incubation conditions and following exposure to some effectors of phagocytosis and different anticoagulants in vitro. The Canadian Journal of Veterinary Research, n.65, p.38-44, 2001.

FEKETY, R. Infections associated with corticosteroids and imunossupressive therapy. Infections diseases. Philadelphia: W. B. Saunders, 1992.

FREITAS, M.; LIMA, J.L.F.; FERNANDES, E. Optical probes for detection and quantification of neutrophils' oxidative burst. A review. Analytica Chimica Acta, n.649, p.8-23, 2009.

JERICÓ, M.M.; MARCO, V. Anti-inflamatórios esteroidais. In. Farmacologia Aplicada à Medicina Veterinária. Rio de Janeiro: Guanabara Koogan, 2011. p.261-271.

KAMPEN, A.H.; TOLLERSRUD, T.; LUND A. Flow cytometric measurement of neutrophils respiratory burst in whole bovine blood using live Staphylococcus aureus. Journal of Immunological Methods, n.289, p.47-55, 2004.

MALAZDREWICH, C.; THUMBIKAT, P.S.; MAHESWARAN, S.K. Protective effect of dexamethasone in experimental bovine pneumonic mannheimiosis. Microbial Pathogenesis, n.36, p.227-236, 2004

PARK, B.H.; GOOD, R.A. N.B.T. Test stimulated. Lancet, n.19, p.616, 1970.

RADOSTITS, O.M.; GAY, C.C.; BLOOD, D.C.; HINCHCLIFF, K.W. Clínica Veterinária: Um tratado de doenças dos bovinos, ovinos, suínos, caprinos e equinos. Rio de Janeiro: Guanabara Koogan, 2002. $1717 \mathrm{p}$.

SOETHOUT, E.C.; MÜLLER, K.E.; VAN DEL BELT, A.J.M.; RUTTEN, V.P.M.G. Identification and phenotyphing of leukocytes in bovine bronchoalveolar lavage fluid. Clinical and Diagnostic Laboratory Immunology, n.11, p.795-798, 2004.

TORRES, R.C.; INSUELA, D.B.R.; CARVALHO, V.F. Mecanismos celulares e moleculares da ação antiinflamatória dos glicocorticoides. Corpus et Scientia, n.8, p.36-51, 2012.

WEISS, R.R.; TREML, T.E.; ABREU, A.C.M.R.; BERTOL, M.A.F.; KOZICKI, L.E.; BERSTEIN, T.C.; KOCH, M.O. Efeito da dexametasona na fertilidade do touro. ArchivesofVeterinary Science, n.20, p.9198, 2015. 